\title{
Termination of Employment Problems in Indonesia
}

\author{
Mukhidin', Achmad Irwan Hamzani2 ${ }^{*}$, Moh. Taufik ${ }^{3}$, Kanti Rahayu ${ }^{4}$, Nuridin ${ }^{5}$ \\ 1,2,3,4,5 Universitas Pancasakti Tegal, Indonesia. \\ *E-mai: al_hamzani@upstegal.ac.id
}

\begin{abstract}
Termination of employment is a complex problem. The impact on unemployment, criminality, and employment opportunities. It takes a harmonious relationship between employers and workers because it has the same interests. The purpose of this study is to describe the termination of employment to workers that should be done by the Company and review the implementation of the Labor Law after the Decision of the Constitutional Court related to Termination of Employment This research uses secondary data, with a normative approach, namely reviewing the issue of termination of employment based on applicable law in Indonesia. The results of this study show that the implementation of termination of employment in Indonesia must be under the Labor Law. Termination of employment is carried out in several processes, namely holding deliberations between workers and the company. If it is deadlocked then the last resort is through the courts. Troubled workers commit serious violations, immediately handed over to the police without asking permission from the authorities. Workers who will retire can be filed under the regulations. Similarly, workers who resign are regulated under company regulations and legislation. Based on the decision of the Constitutional Court, employers can break the employment relationship against workers because they have committed serious violations. Severe errors must be supported with some evidence. There has been a shift in the guilty judgment of workers, especially when it comes to criminal acts that are the authority of the court.
\end{abstract}

Keywords

Termination of Employment, Impact, Rights.

Article Received: 10 August 2020, Revised: 25 October 2020, Accepted: 18 November 2020

\section{Introduction}

Termination of Employment (layoffs) is an undesirable thing by both parties, especially workers who are in a weak position compared to employers. Termination of employment is a complex problem because it has to do with unemployment, criminality, and employment opportunities (Dwita, 2014). The impact of termination of employment is often a major problem for the state, which has a considerable impact on social subsidies. It will automatically erode the state budget that should be allocated to the development budget. Along with the pace of modernization of national and state life, business industry and the increasing number of the labor force working in working relationships. The issue of termination of employment is always an issue because it concerns problems for citizens.

The consequences of termination of employment are mainly for workers and their families. Termination of employment for workers is the beginning of the problem. It means the beginning of the end of having a job, the beginning of the end of the ability to finance daily living needs for his family, the beginning of the end of the ability to send children to school, and so on (Dwita, 2014). Termination of employment means loss of employment and loss of income for the family. Law of the Republic of Indonesia Number 13 of 2003 concerning Employment regulates termination of employment. The Company cannot arbitrarily terminate the employment relationship unilaterally. Because the implications are very broad for the company itself and also for workers (Nurwanti, et. al., 2012).

To create a healthy and conducive atmosphere for workers and companies, a harmonious relationship should be created. Reciprocity because it has a common interest. If there is a harmonious relationship, it gives a heavy psychological impact for workers in doing their work activities. The impact will decrease the productivity of work, so it will certainly also influence the company's performance. These two parties must be in line in communication, atmosphere, and work process, to be able to get a comsensalis profit.

A good worker is a worker who performs his duties well. This is contained in Article 1603 of the Civil Code. It is mentioned that to carry out the obligations of workers carrying out their work 
according to the best ability, do not represent the work to third parties without the permission of the entrepreneur and obey all the rules of the company without coercion. If any rules are violated, be it minor mistakes or gross errors, then it is attempted to be resolved by family relations and with a good rebuke (Hajj, 2019).

The attitude and behavior of workers affect their qualifications in work and it is the authority of employers, one of which is about the discipline of work. Work discipline is the awareness and willingness of a person to obey all company regulations and social norms that apply and show a condition or respect that exists in the self things to the rules and regulations of the company. For employers, the existence of work discipline will ensure the maintenance of discipline and smooth implementation of tasks so that optimal results are obtained. As for the work discipline workers will create a pleasant working atmosphere. The working spirit of workers is also increasing. This allows workers to carry out their work with full awareness. Work discipline does not eliminate any dissatisfaction from employers. The basic points of dissatisfaction of employers towards workers include assignment behavior that is not under personality, as well as personal problems between workers and employers (Nurwanti, 2012).

Violations in employment relationships are sometimes also caused by differences in understanding in the implementation of employment law. Differences in understanding are seen through the perspective of judges and businessmen. Despite ultimately winning the case, the businessman is still found guilty by a judge (Joni, 2015).

As a sensitive issue, employers should be wise in terminating employment because it can decrease the welfare of the community. It can even lead to unemployment. Termination of employment is a scourge for workers, considering the many impacts and consequences they cause. Not only for the workers themselves even this is like a domino effect that is interconnected with each other and penetrates other secretaries of public life. The government, employers, workers, and their unions should try not to cause termination of employment (Kasim, 2004).

Companies often have difficulty in implementing a policy of termination of employment relationships. This is because the policy of termination of employment is interpreted as a policy that does not pay attention to workers. The company's termination policy is not necessarily a policy that harms workers. The problem of termination of employment can be seen from two contexts; a good understanding of modern management regulations and contexts. These two things are important to avoid disputes that can be detrimental to both parties, both companies, and workers. Based on that background, the problem studied in the study is the implementation or termination of employment to workers that should be done by the company, as well as the implementation of the Labor Law after the Decision of the Constitutional Court related to the termination of employment.

\section{Research Methods}

The approach used in this study is normative. The normative approach in legal research is to examine legal issues with a positive legal perspective. This research uses a normative approach because it examines environmental protection based on applicable laws and regulations, namely state administrative law. The data source used by this research is secondary data. Secondary data is data obtained indirectly or has been provided by other parties. Secondary data used in the form of legal documents that are used as the main reference to review environmental protection perspectives of state administrative law. Data collection techniques were used in this study through offline and online investigation. Offline library smoothing is the activity of finding the source of the library to the data store. While online graduation is the activity of finding library sources in cyberspace through the internet network. Conventional library graduation is done by looking for library materials to libraries, collections of books and personal journals, purchasing books, and visiting scientific activities (seminars). While online smoothing is done by searching the internet. The data analysis method used is qualitative. Qualitative data analysis is the process of organizing and sorting data into patterns, categories, and units of the basic description so that themes can be found presented in the form of narratives (Hamzani, 2020). This research uses qualitative data analysis because the data will be presented narratively- 
descriptively, not in the form of numbers or numerical.

\section{Discussion}

\section{Termination of Employment with Workers that should be done by the Company}

Termination of employment is something that workers are very afraid of. Even termination of employment becomes a negative thought because it is considered a dismissal. Whereas termination of employment is a process of continuity of the company. It is expected that the Law of the Republic of Indonesia No. 13 of 2003 on Manpower and the Law of the Republic of Indonesia No. 2 of 2004 on Settlement of Industrial Relations Disputes can protect against the threat of unilateral termination of employment in Indonesia (Prameswari, et. al., 2020).

Mentioned in Article 1 number 4 of the Law of the Republic of Indonesia Number 2 of 2004 concerning The Settlement of Industrial Relations Disputes that the dispute of termination of employment is a dispute arising from the absence of conformity of opinion regarding the termination of the employment relationship conducted by one of the parties. Termination of employment means relating to the fulfillment of workers' economic rights and the financial condition of the company. It is only natural that the government intervenes.

Dismissal of workers should be based on laws and regulations so as not to cause problems, and be done in the best way possible as when they are accepted as workers. Thus, the relationship between the company and former workers remains well established. But in reality, there is often a dismissal with dismissal, because of the insurmountable conflict, which should be the dismissal of workers must be based on rules and regulations (Haji, 2019).

There are 8 (eight) reasons for termination of employment, namely, because of the law, the wishes of the company, the wishes of workers, pensions, contracts of employment expired, health Workers, death, and liquidated companies. A company's wishes can cause a person to be dismissed from the company, either honorably, or fired. Application for termination of employment permit can be granted if the laborer commits a major violation/mistake (Prameswari, et. al., 2020).

Dismissals based on the company's wishes may occur because the worker is elderly and has no more benefits for the company. The worker is elderly, incompetent, or commits adverse acts such as corruption.

Factors causing termination of employment conducted by the company in the Labor Law caused: First, the company suffered a setback so that it needs to rationalize or reduce the number of workers/workers. Termination of employment because of rationalization or minor mistakes of workers determined that employers, workers, unions/workers, and the government seek to prevent termination of employment. Such efforts have been made, but termination of employment is inevitable, then the intention of termination of employment must be negotiated by companies and unions or workers if the worker/laborer does not become a member of the union.

Second, the worker has made a mistake, either the mistake violates the provisions listed in the company's regulations as an employment agreement. For workers who are disconnected from employment, the Government emphasizes the factors that cause termination of employment. The hope is that employers do not unilaterally terminate the employment of workers. One of the important points is the prohibition of termination of employment if the person is performing worship ordered by his religion. It seems that the theory of government concern with fighting for the right of workers or workers to carry out worship that is ruled by their religion (Joni, 2015). Three stages must be taken in terms of employers wanting to break the working relationship with workers. First, employers, workers, unions, governments, with all efforts must try to avoid termination of employment. Second, if with all efforts made, it is inevitable that termination of employment then the intention to sever employment must be negotiated by employers and unions or with workers if the worker is not a member of the union. Third, if the negotiations do not produce approval, the employer can only sever employment with workers after obtaining a determination from the Institute for the Settlement of Industrial Relations (Haji, 2019).

The termination of employment begins a difficult time for workers and their families. To help or at 
least reduce the burden on laid-off workers, the law requires employers to provide severance money, award money, and reimbursement money. The reason for the dismissal plays a major role in determining whether or not the worker is entitled to severance money, award money, and reimbursement of rights. Severance money, award money, and reimbursement of rights are regulated in the Employment Law.

With the employment relationship, the worker is entitled to wages in return for his work. While the employer is entitled to the services/goods of the worker's work under the agreed employment agreement. Termination of employment between workers and employers should not be done arbitrarily. Certain things must be fulfilled by both parties so that the dismissal does not harm the sense of justice between the two sides (Darwan, 2000).

The law in Indonesia also provides complete rules about what employers must pay in the event of termination of employment. These obligations include payment of severance money, award money for the period of employment, and reimbursement of rights that should be received. The amount or amount of severance money and other award money to be paid is attributed to the monthly wages and length of employment of the worker. Wages, in this case, include basic wages and all kinds of allowances that are fixed and taken into account under the established rules.

There are components used in the calculation of severance money and award money. The wage component is used as the basis for the calculation of severance money, employment award money, and delayed reimbursement of entitlements consisting of basic wages and all kinds of fixed benefits provided to workers and their families.

\section{Implementation of Employment Law after the Decision of the Constitutional Court Related to Termination of Employment}

Controversy occurred over the enactment of the Labor Law in Indonesia with the decision of the Constitutional Court of The Republic of Indonesia. No. 012/PUU-I/2003. When viewed backward, the controversy arises since the discussion of the Law of the Republic of Indonesia Number 25 of 1997 on Employment, until it is postponed. The delay in enforcement shows the government's high attention to employee development.

The existence of such controversy can be understood because the provisions stipulated in the Labor Law are essentially governing 2 (two) wishes that are always not aligned, namely the wishes of workers on one side and the wishes of employers on the other. The difference in desire is inseparable from the development of industrialization that resulted in the onset of the socio-economic revolution. Industrialization, on the one hand, has led to tremendous economic progress, but on the other hand, it also poses a variety of problems in the social field as well as in the economic field itself. This is characterized by the emergence of the working class as salespeople and or thoughts that differ socioeconomically from the business class as owners of capital and production tools (Haji, 2019).

Competition between employers for a large profit has given rise to a tendency for employers to suppress workers' wages. Instead of workers, who depend on their lives on wages, will struggle to earn high wages. Although juridically the position of workers is the same as the employer, sociologically the position of the entrepreneur is stronger when compared to the position of the worker, as a factor of production

With the decision of the test case of the Law of the Republic of Indonesia No. 13 of 2003 on Manpower with the decision of the case No. 012/PUU-1/2003, the polemic is completed. The enactment of Law of the Republic of Indonesia Number 13 of 2003 concerning Employment has legal force and is binding. However, there is some canceled material.

Facing the complexity faced by Indonesia, it cannot be black and white, but rather must interpret the law and constitution in other fields more dynamically and contextually. Based on this, the Constitutional Court held that in the market economy government interference through market economic policies and arrangements should be done proportionally. The ideas contained in Article 33 of the 1945 Constitution must remain the philosophy and system of norms in the Constitution as the supreme law of the land. From the Constitution will flow a series of rules and policies that are compatible for the greatest prosperity of the people. Market law will be influenced propositionally to eliminate distortions 
and market weaknesses and can be eliminated while considering the risks that investors will experience through balanced and reasonable incentives (Hajj, 2019).

Observing changes in termination arrangements in the Employment Law, especially regarding the termination of employment with gross misconduct, there has been a change in the principle of termination of employment. Arrangement of termination of employment because of gross error, previous employers can perform termination of employment after obtaining permission or determination from the Regional / Central Committee. The provision is contained in Article 170 of the Employment Law, i.e. employers do not have to apply for a termination permit as long as the gross error is supported by evidence. For example, workers caught hands, the recognition of the worker/laborer concerned, or there is other evidence in the form of a report of events made by the authorities in the company concerned and supported by at least 2 (two) witnesses.

With this provision, there has been a shift in the guilty judgment of workers, especially when it comes to criminal acts that are the authority of the court. If it meets one of the shreds of the evidence above, employers can hold termination of employment without the permission of the Regional / Central Committee or determination. The businessman, in this case, has exercised the authority of the court.

If the termination arrangement is observed because the worker has made a serious mistake before, the employer before terminating the employee must apply for a termination permit to the Regional / Central Committee. Looking at the working relationship between workers and employers is a civil relationship, which is based on agreement. To end the working relationship and remember the position of workers socially the economy weak, it is necessary to permit relationships issued by the Regional / Central Committee.

The Regional/Central Committee in the case of a request for termination of employment permit based on gross misconduct is not assessing whether the act is under the elements of a criminal act or not. But looking at the termination of employment in terms of employment relationships based on civil law is that an agreement must be done ethically well. In the form of evidence submitted by employers, the Regional / Central Committee can assess workers in conducting work relationships whether workers are good or not. Not assessing whether the reason employers meet the elements of criminal acts or not. It is outside the authority of the Regional / Central Committee and businessmen (Haji, 2019).

The Constitutional Court through its consideration has conducted an assessment of the decision of the working relationship on the grounds of gross misconduct made through the due process of law, namely through the decision of an independent court. It is not the employer's authority to decide that the worker has committed a criminal offense. The process of termination of employment on the grounds of gross misconduct can still be enforced. However, to declare the termination of the working relationship, the Regional / Central Committee or Institution through the application of employers by attaching evidence. Regional / Central Committee or Industrial Relations Dispute Resolution Institute in its research is in the framework of civil working relationships.

With the decision of the Constitutional Court, especially regarding the termination of employment on the grounds of gross misconduct that ruled that Article 158, Article 159, Article 170 as long as it concerns the clauses "except Article 158 paragraph (1)" and Article 171 as long as it concerns the clause "Article 158 paragraph (1)", has no binding legal force. This resulted in that the Employment Law, especially regarding the termination of employment does not recognize the termination of employment on the grounds of gross misconduct. It can also be interpreted based on the historical interpretation that, termination of employment on the grounds of gross misconduct as stipulated in Article 158 remains.

To hold termination of employment employers still need to obtain permission through an application to the Regional Committee / Center or Industrial Relations Court by attaching evidence of such gross misconduct. With the provision of having to obtain a permit, then under Article 159 of the Labor Law is not required because workers at the time of applying for a permit can hold a defense effort at the regional/central committee level. Similarly, Article 170 and Article 171 as long as it concerns Article 158 paragraph (1) of the Employment Law, has no binding legal force. 
The decision of the Constitutional Court also has an impact on the Law of the Republic of Indonesia Number 2 of 2004 concerning the Settlement of Industrial Relations Disputes, especially against Article 82, as long as it concerns ..." Article 159" has no binding legal force and the clause "Article 171" does not include Article 158 paragraph (1) of the Employment Law.

When using the interpretation that the Labor Law, especially regarding the termination of employment, does not recognize the termination of employment because of gross misconduct. These provisions will also affect the arrangement of the working conditions outlined in the Employment Agreement, Company Regulations, or Collective Labor Agreements governing the reasons for gross misconduct.

\section{Conclusion}

Based on the above discussion, it can be concluded that the implementation of termination of employment conducted by the company must be under the Law of the Republic of Indonesia Number 13 of 2003 concerning Employment. Termination of employment is carried out in several processes, namely holding deliberations between workers and the company. If it is deadlocked then the last way is through the court to decide the case. Troubled workers commit serious violations, immediately handed over to the police without asking permission from the authorities. Meanwhile, workers who will retire can be submitted under the regulations. Similarly, workers who resign are regulated under company regulations and legislation. Based on the decision of the Constitutional Court on the Employment Law related to the termination of employment, employers can break the employment relationship against workers because they have committed serious violations. Gross misconduct must be supported by some evidence, such as the worker being caught by hand, there is an acknowledgment from the worker concerned, and a report of the incident made by the authorities supported by at least two witnesses. There has been a shift in the guilty judgment of workers, especially when it comes to criminal acts that are the authority of the court. If it meets one of the shreds of evidence above, employers can hold termination of employment without the permission of the Regional / Central Committee or determination.

\section{References}

[1] Darwan, Prints (2000). Indonesian Labor Law. Bandung: PT Citra Aditya.

[2] Dwita, Erni (2014). Termination of Employment from a Legal Perspective (Case Study PT. Medco Lestari Papua). Journal of Economic \& Social Sciences, 5 (2).

DOI:https://doi.org/10.35724/jies.V5i2.70.

[3] Haji, Son (2019). Juridical Analysis of Layoffs Due to Worker Errors. Administrative Law and Governance Journal, 2(1).

[4] Joni, R. Bambang (2015). Employment Law. Bandung: Pustaka Setia.

[5] Kasim, Umar (2004). Employment Relations and Termination of Employment. Jurnal Informasi Hukum, 2(1).

[6] Code of Civil law.

[7] Nurwanti, Isti, et. al. (2012). Legal Protection of Workers' Rights due to Termination of Employment. Jurnal Hukum Perdata. 1 (2).

[8] Prameswari, Karina, et.al. (2020). Layoff Arrangements between Workers and Companies. Mizan: Journal of Legal Studies, 12(1). $2020 . \quad$ DOI: https://doi.org/1032503/mizan.v7iI.923.

[9] Decision on Case of the Constitutional Court of the Republic of Indonesia No. 012/PUU-1/2003.

[10] Law of the Republic of Indonesia Number 13 of 2003 concerning Manpower.

[11] Law of the Republic of Indonesia Number 2 of 2004 concerning Settlement of Industrial Relations Disputes. 